\title{
Underexpression of Deleted in liver cancer 2 (DLC2) is associated with overexpression of RhoA and poor prognosis in hepatocellular carcinoma
}

\author{
Li Xiaorong*, Wu Wei, Qian Liyuan and Yang Kaiyan
}

\begin{abstract}
Address: Department of General Surgery, The Third Affiliated Hospital of Central South University, Central South University, Tongzhipo Road, Changsha, Hunan Province, 410013, PR China

Email: Li Xiaorong* - lixiaorong_x@hotmail.com; Wu Wei - wuweixy@hotmail.com; Qian Liyuan - qianlycsu@hotmail.com; Yang Kaiyan - soskinghero@126.com

* Corresponding author
\end{abstract}

Published: 23 July 2008

BMC Cancer 2008, 8:205 doi:10.1 186/147/-2407-8-205

This article is available from: http://www.biomedcentral.com/I47I-2407/8/205

(c) 2008 Xiaorong et al; licensee BioMed Central Ltd.

This is an Open Access article distributed under the terms of the Creative Commons Attribution License (http://creativecommons.org/licenses/by/2.0), which permits unrestricted use, distribution, and reproduction in any medium, provided the original work is properly cited.
Received: I January 2008

Accepted: 23 July 2008

\begin{abstract}
Background: DLC2, a unique RhoGAP, has been recently identified as a tumor suppressor gene in hepatocellular carcinoma (HCC). However, the expression of DLC2 protein, and its relationship with RhoA in clinical hepatocellular carcinoma have not been studied. The aim of this study was to investigate the DLC2 protein expression and its correlation with expression of RhoA, as well as to evaluate the prognostic value of DLC2 for HCC patients.
\end{abstract}

Methods: Western blot and immunohistochemical staining were employed to detect DLC2 protein expression in $128 \mathrm{HCC}$ specimens. The correlation between DLC2 protein expression and clinicopathologic outcome, and prognostic value of DLC2 for HCC patients were analyzed.

Results: HCC tissues revealed significantly lower level of DLC2 protein than pericarcinomatous liver tissues (PCLT). There was significant correlation between underexpression of DLC2 protein and cell differentiation. Meanwhile, underexpression of DLC2 protein was correlated with overexression of RhoA. Furthermore, HCC Patients with DLC2-negative expression showed a significantly poorer prognosis than those with DLC2-positve expression.

Conclusion: Our data strongly suggested that decreased DLC2 expression in HCC correlates with cell differentiation of HCC and overexpression of RhoA, underexpression of DLC2 is associated with poor prognosis in HCC patients.

\section{Background}

Hepatocellular carcinoma (HCC) is one of the most common malignancies in Asia and Africa, especially in China $[1,2]$. It is responsible for approximately one million deaths each year, predominantly in the developing countries [3]. During the past decades, hepatic resection for HCC has evolved into a safe procedure with low operative mortality [4,5]. However, the molecular mechanisms leading to the development and progression of hepatocellular carcinoma remains unclear. Thus, the delineation of the mechanisms for hepatocarcinogenesis is of importance, because it provides novel opportunities for diagnosis, prognosis, and therapeutic interventions.

RhoA-GTPase is a member of the Ras-superfamily of small guanosine triphosphatases (GTPases), which shuttles 
between an inactive GDP-bound state and an active GTPbound state and exhibits intrinsic GTPase activities [6]. Activation of Rho protein causes to assembly of the actinmyosin contractile filaments into focal adhesion complexes that leads to cell polarity and facilitate motility [7]. In human cancers, the alteration of RhoA expression is involved in tumorigenesis. Indeed, overexpression of RhoA was detected in several types of cancer including bladder, testicular, ovarian, colon, breast, and lung [8-11]. Our previous study revealed that overexpression of RhoA was associated with poor prognosis in hepatocellular carcinoma [12]. As activating of RhoGTPases can stimulate cell proliferation and cell motility, inhibition of the RhoA activity may suppress the oncogenic and metastatic potential of tumor cells. Recently, a unique RhoGAP, which named DLC2 (deleted in liver cancer 2) because of its high homology to tumor suppressor gene DLC1, has been identified [13]. DLC2 contains a RhoGAP domain and exhibits GAP activity on RhoA and Cdc42 in vitro. Researches show that DLC2 suppresses cell transformation by means of inhibition of RhoA activity in hepatocellular carcinoma cells [14], meanwhile DLC2 mRNA is underexpressed in human hepatocellular carcinoma, which suggested a potential prognostic value of DLC2 for HCC patients.

However, there has been no available data on the protein expression of DLC2 in clinical hepatocellular carcinoma. Does DLC2 protein underexpress in hepatocellular carcinoma? Or does its expression correlate with clinicopathological parameters of HCC and expression of RhoA? Especially, whether DLC2 is a valuable prognostic marker for HCC patients? In this study, therefore, we examined the DLC2 protein expression in HCC and evaluated the relationship between DLC2 expression and clinicopathological parameters of HCC. Meanwhile, we investigated the relationship between expression of DLC2 and RhoA; most importantly, the prognostic value of DLC2 for HCC patients was also investigated.

\section{Methods \\ Tissue specimens}

The study protocol was approved by the Ethics Committee of the Central South University. Fresh samples of HCC tissue and pericarcinomatous liver tissue (PCLT, $1 \mathrm{~cm}$ away from the carcinoma) were obtained from 53 (46 male and 7 female) patients with primary hepatocellular carcinoma who underwent curative hepatectomy at the Third Affiliated Hospital of Central South University (CSU) during 2000 to 2003 . The specimens were immediately frozen in liquid nitrogen and stored at $-80^{\circ} \mathrm{C}$ for western blotting. The median age of these patients was 55 year, ranging from 19 75 year. All specimens obtained from hepatic resection were confirmed by pathological examination and clinicopathological parameters such as tumor diame- ter, number of tumor node, tumor capsule, histopathological classification, venous invasion, extrahepatic metastatic lesion and hepatitis virus infection were obtained.

\section{Antibody}

Because there is no commercial DLC2 antibody at present, a mouse anti-human DLC2 monoclonal antibody was developed through ProMab Company. Brief, a 15aa polypeptide representing a unique epitope was synthesized according to the full-length DLC2 sequence [15], then the polypeptide was coupled with KLH. After injection in mouse, immune serum was obtained following standard techniques. Western blot confirmed the specificity of the antibody for DLC2. The quality control examination showed that the antibody is valid.

\section{Western blotting}

Tissues from HCC and PCLT were lysed in a lysis buffer (Sigma, St. Louis, MO, USA) and protease-inhibitor (Promega, Madison, USA). The lysates were centrifuged at $13,000 \mathrm{~g}$ for $20 \mathrm{~min}$ at $4{ }^{\circ} \mathrm{C}$ and the supernatants were stored at $-80^{\circ} \mathrm{C}$. Extracts equivalent to $50 \mu \mathrm{g}$ of total protein were separated by SDS-PAGE gel and were blotted to polyvinylidene fluoride membrane (Sigma, St. Louis, MO, USA). After they were blocked in $4 \%$ nonfat dry milk in PBS containing $0.1 \%$ Tween- 20 for $1 \mathrm{~h}$ at room temperature, the membranes were incubated with primary antibody (mouse anti-human DLC2 monoclonal antibody, ProMab, China, diluted at 1:500) for $1 \mathrm{~h}$ at $37^{\circ} \mathrm{C}$. After washing, the membranes were incubated with a 1:5000 dilution of horseradish peroxidase-linked rabbit antimouse antibody (ProMab, China) for 30 mins at $37^{\circ} \mathrm{C}$. Then the membranes were washed and treated with western blotting luminal reagent (Santa Cruz, California, USA) to visualize the bands, the results were obtained on Kodak film and quantified by densitometry (Beckman, South Pasadena, Canada) [16].

\section{Immunohistochemistry}

One hundred and twenty-eight HCC deparaffinized specimens, including the 53 cases of HCC fresh specimens used for Western blotting, were evaluated for immunohistochemistry. All the specimens were collected from the Third Affiliated Hospital of Central South University (CSU) between 1991 and 2003. The clinicopathological parameters of all the specimens, including tumor diameter, number of tumor node, tumor capsule, histopathological classification, venous invasion, extrahepatic metastatic lesion and hepatitis virus infection were obtained. Follow-up data was obtained following the operations for all patients; the endpoint of the follow-up was set at the patients' death. In brief, tissue sections of 4 $\mu \mathrm{m}$ thick were cut and baked at $60^{\circ} \mathrm{C}$ for $2 \mathrm{~h}$, deparaffinized in xylene and rehydrated through graded ethanol. 
Next, 3\% hydrogen peroxide was applied to block the endogenous peroxidases for 20 mins, and the sections were subjected to heat-induced antigen retrieval in $0.01 \mathrm{M}$ citrate buffer $(\mathrm{PH}=6.0)$. The sections were incubated with normal rabbit serum to reduce non-specific binding. Then, they were incubated at $37^{\circ} \mathrm{C}$ for $1 \mathrm{~h}$ with specific antibodies (mouse anti-human DLC2 monoclonal antibody, ProMab, China) used at a 1:50 dilution. The second antibody was applied for $45 \mathrm{~min}$ at $37^{\circ} \mathrm{C}$. The Streptavidin-biotin-peroxidase complex (SABC) tertiary system (Boster, Wuhan, China) was used according to the manufacturer's instruction for $20 \mathrm{~min}$ at room temperature. The tissues were visualized by applying 3, 3-diaminobenzidine tetrahydrochloride (DAB) for $3 \mathrm{~min}$. Sections were counterstained using haematoxylin, dehydrated through gradient alcohols and mounted for viewing. Negative controls were done by omitting the primary antibody, whereas, HCC specimens of high DLC2 expression confirmed by Western blotting were used as positive controls. The intensity of cytoplasmic staining was scored as 0 to $3+$ by comparison to the positive controls. DLC2-negative expressions were devoid of any cytoplasmic staining or contained faint, equivocal staining (scores 0 and 1+) [12].

\section{Statistical analysis}

Statistical analysis was performed using the SPSS (version 11.0, Chicago, IL). A Student's t test was used to analyze the expression of DLC2 between HCC and PCLT. Spearman's correlation coefficient was used to examine the relationship between expression of DLC2 and RhoA. The Mann-Whitney $U$ test and chi-square test were monitored to analyze the correlation between the expression of DLC2 and clinicopathological variables. Post-operative overall survival was analyzed by the Log-rank test. Differences were considered significant when $P<0.05$.

\section{Results}

\section{Expression of DLC2 protein in HCC and PCLT}

Expression of DLC2 protein was detected in all HCC and PCLT. The relative expression of DLC2 protein was $0.40 \pm$ 0.06 in HCC and $0.57 \pm 0.08$ in PCLT respectively. HCC tissues revealed significantly lower levels of DLC2 protein than PCLT $(P=0.02)$ (Figure 1).

\section{Correlation between DLC2 expression levels and clinicopathological parameters of HCC}

The distribution pattern of DLC2 was determined by dividing the expression levels of DLC2 protein in subgroups by clinicopathological parameters. HCC with poor cell differentiation showed a lower expression level of DLC2 protein than those with well cell differentiation. There were no significant associations between expression of DLC2 gene and other clinicopathological parameters such as sex, hepatitis virus infection, liver cirrhosis, tumor size and capsular condition, venous invasion and nodular

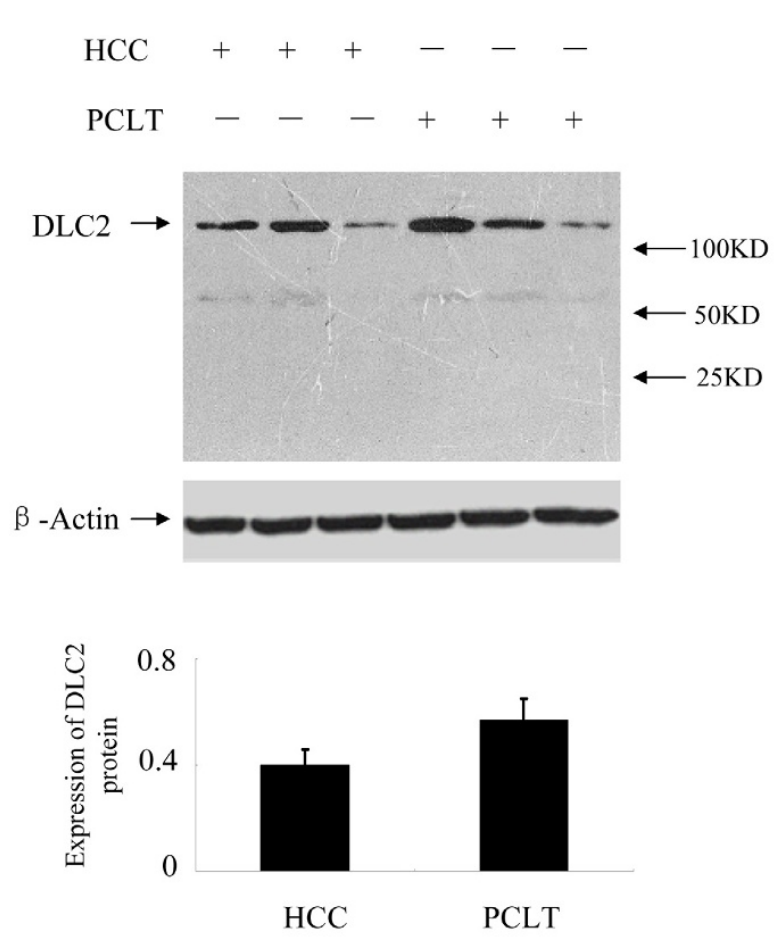

Figure I

Expression of DLC2 protein. Expression of DLC2 protein was detected in 53 cases of HCC fresh specimens using western blot, HCC tissues revealed significantly lower levels of DLC2 protein than PCLT. $P=0.02$.

number (Table 1). The same result was observed based on the correlation between immunohistochemical study and clinicopathological parameters of 128 cases of HCC specimen (Table 2).

\section{Correlation between DLC2 expression and RhoA expression}

The protein expressions of DLC2 and RhoA were examined simultaneously. The protein expressions of DLC2 and RhoA showed strongly negative correlation. (correlation coefficient $=-0.447, P=0.01)$ (Figure 2).

\section{Correlation between DLC2 expression and prognosis of HCC}

To further investigate the correlation between DLC2 expression level and prognosis, HCCs were divided into the DLC2 negative expression group (immunohistochemistry score 0 and $1+; \mathrm{n}=95$ ) and DLC2 positive expression group (immunohistochemistry scores $2+$ and $3+; \mathrm{n}=33$ ). DLC2 expression level and the prognosis of HCC patients were analyzed by Kaplan-Meier method. The result showed the mean overall survival of patients with DLC2- 
Table I: The relationship between expression level of DLC2 protein and clinicopathological parameters for 53 cases of HCC specimen.

\begin{tabular}{|c|c|c|c|}
\hline $\begin{array}{l}\text { Clinicopathological } \\
\text { parameters }\end{array}$ & No. of patients & $\begin{array}{l}\text { Expression of } \\
\text { DLC2 protein }\end{array}$ & $P$ value \\
\hline \multicolumn{4}{|l|}{ Sex } \\
\hline Male & 46 & $0.41 \pm 0.08$ & 0.49 \\
\hline Female & 7 & $0.39 \pm 0.06$ & \\
\hline \multicolumn{4}{|l|}{ Liver cirrhosis } \\
\hline Present & 32 & $0.39 \pm 0.04$ & 0.78 \\
\hline Absent & 21 & $0.40 \pm 0.07$ & \\
\hline \multicolumn{4}{|c|}{ Hepatitis virus infection } \\
\hline Present & 47 & $0.41 \pm 0.04$ & 0.72 \\
\hline Absent & 6 & $0.40 \pm 0.05$ & \\
\hline \multicolumn{4}{|l|}{ Capsule formation } \\
\hline Present & 27 & $0.40 \pm 0.04$ & 0.63 \\
\hline Absent & 26 & $0.39 \pm 0.06$ & \\
\hline \multicolumn{4}{|l|}{ Tumor nodule } \\
\hline$\geq 2$ & 35 & $0.42 \pm 0.10$ & 0.23 \\
\hline$<2$ & 18 & $0.39 \pm 0.06$ & \\
\hline \multicolumn{4}{|l|}{ Cell differentiation* } \\
\hline $\mathrm{I} \sim \mathrm{II}$ & 24 & $0.42 \pm 0.06$ & $0.02^{* *}$ \\
\hline III IV & 29 & $0.38 \pm 0.05$ & \\
\hline \multicolumn{4}{|l|}{ Vein invasion } \\
\hline Present & 26 & $0.41 \pm 0.09$ & 0.13 \\
\hline Absent & 27 & $0.39 \pm 0.13$ & \\
\hline \multicolumn{4}{|c|}{ Extrahepatic metastasis } \\
\hline Present & 11 & $0.40 \pm 0.06$ & 0.34 \\
\hline Absent & 42 & $0.39 \pm 0.08$ & \\
\hline \multicolumn{4}{|l|}{ Tumor size } \\
\hline$>5 \mathrm{~cm}$ & 38 & $0.41 \pm 0.06$ & 0.57 \\
\hline$\leq 5 \mathrm{~cm}$ & 15 & $0.40 \pm 0.09$ & \\
\hline
\end{tabular}

*classified by Edmondson-Steiner grade

**by Mann-Whitney $U$ test, $P<0.05$

negative expression (414 days) was significantly lower than those of patients with DLC2-positive expression (697 days, $P=0.003$ ). HCC Patients with DLC2-negative expression revealed significantly poorer prognosis than those with DLC2-positive expression (Figure 3).

\section{Discussion}

Although DLC2 has been identified as a tumor suppressor gene in HCC, the expression of DLC2 protein, especially the relationship with RhoA in clinical hepatocellular carcinoma has not been studied. The previous study demonstrated that the mRNA expression of DLC2 was significantly lower in HCC than in PCLT [13]. In human neoplasms, it has been reported that DLC2 was down-regulated in lung, ovarian, renal, breast, uterine, gastric, colon and rectal tumor [17]. Also, underexpression of DLC2 was confirmed to be help for invasion and migration of hepatocellular carcinoma cells [14]. Consistent with previous documents, our present study shows that DLC2, on protein level, is down-regulated in HCC, which
Table 2: The correlation between immunohistochemical studies and clinicopathological parameters for $\mathbf{2 8}$ cases of HCC specimens.

\begin{tabular}{|c|c|c|c|c|}
\hline \multirow{2}{*}{$\begin{array}{l}\text { Clinicopathological } \\
\text { parameters }\end{array}$} & \multirow{2}{*}{$\begin{array}{l}\text { No. of } \\
\text { patients }\end{array}$} & \multicolumn{2}{|c|}{ DLC2 expression } & \multirow[t]{2}{*}{$P$ value } \\
\hline & & Positive & Negative & \\
\hline \multicolumn{5}{|l|}{ Sex } \\
\hline Male & 116 & 30 & 86 & 0.95 \\
\hline Female & 12 & 3 & 9 & \\
\hline \multicolumn{5}{|l|}{ Liver cirrhosis } \\
\hline Present & 80 & 20 & 60 & 0.79 \\
\hline Absent & 48 & 13 & 35 & \\
\hline \multicolumn{5}{|c|}{ Hepatitis virus infection } \\
\hline Present & 107 & 25 & 82 & 0.15 \\
\hline Absent & 21 & 8 & 13 & \\
\hline \multicolumn{5}{|l|}{ Capsule formation } \\
\hline Present & 71 & 18 & 53 & 0.91 \\
\hline Absent & 57 & 15 & 42 & \\
\hline \multicolumn{5}{|l|}{ Tumor nodule } \\
\hline$\geq 2$ & 82 & 19 & 63 & 0.36 \\
\hline$<2$ & 46 & 14 & 32 & \\
\hline \multicolumn{5}{|l|}{ Cell differentiation* } \\
\hline $\mathrm{I} \sim \mathrm{II}$ & 52 & 20 & 32 & $0.01 * *$ \\
\hline III IV & 76 & 13 & 63 & \\
\hline \multicolumn{5}{|l|}{ Vein invasion } \\
\hline Present & 54 & 16 & 38 & 0.39 \\
\hline Absent & 74 & 17 & 57 & \\
\hline \multicolumn{5}{|c|}{ Extrahepatic metastasis } \\
\hline Present & 28 & 9 & 19 & 0.38 \\
\hline Absent & 100 & 24 & 76 & \\
\hline \multicolumn{5}{|l|}{ Tumor size } \\
\hline$>5 \mathrm{~cm}$ & 70 & 18 & 52 & 0.98 \\
\hline$\leq 5 \mathrm{~cm}$ & 58 & 15 & 43 & \\
\hline
\end{tabular}

*classified by Edmondson-Steiner grade

**by Chi-square test, $P<0.05$

indicates that DLC2 may participate in hepatocarcinogenesis.

To investigate how DLC2 affects hepatocarcinogenesis, we evaluated the correlation between DLC2 expression level and clinicopathological parameters of HCC. Our results show that the expression of DLC2 protein is lower in HCC than PCLT, which is more frequently associated with cell differentiation. This result is consistent with the role of DLC2 as a tumor suppressor gene in HCC. As previous study indicated that DLC2 encodes a RhoGAP protein with growth suppressor function in hepatocellular carcinoma, we hypothesized that DLC2 may down-regulate expression of RhoA. Thus, the protein expression of DLC2 and RhoA were examined simultaneously in human hepatocellular carcinoma. Anticipatively, the protein expression of DLC2 and RhoA showed strongly negative correlation, which was consistent with the hypothesis that DLC2 suppresses hepatocarcinogenesis by means of inhi- 


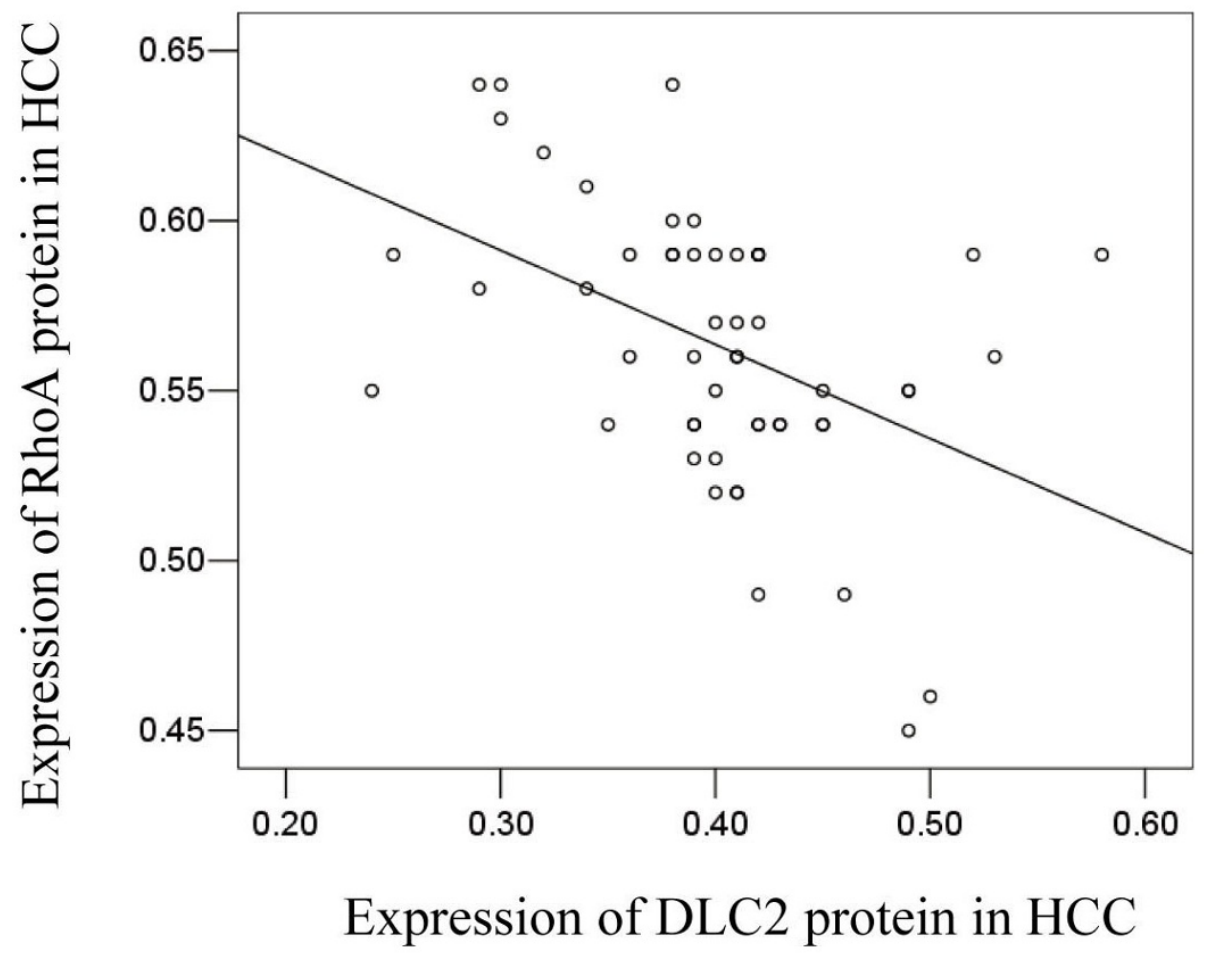

\section{Figure 2}

Correlation between DLC2 protein expression and RhoA protein expression. Correlation between DLC2 protein expression and RhoA protein expression was evaluated by Spearman's correlation coefficient. DLC2 protein levels were negative correlated with the levels of RhoA protein in HCC with adjusted -0.447 and two-tailed probability, $n=53, P=0.0 \mathrm{I}$.

bition of RhoA activity [14]. However, there was no evidence to confirm the direct relationship between DLC2 and RhoA. The increase in RhoA protein in HCC samples observed in our study may not be a direct result of reduced DLC2 expression, but could be due to cancer-related alterations in upstream factors that regulate the two genes. Therefore, the further investigation is anticipated.

In our study, the underexpression of DLC2 correlates with cell differentiation, which suggests a possibility that DLC2 expression could be used as a potential prognostic marker for HCC patients. To explore this possibility, anti-DLC2 immunohistochemical staining was performed on 128 cases of HCC specimens. Because of lower detection sensitivity of the immunohistochemistry method, some of the 128 cases of HCC show negative staining of DLC2, notwithstanding DLC2 protein is detected in all 53 cases of HCC with western blotting. Nevertheless, when we divide the total cases of HCC into either DLC2 positive or negative group, the DLC2-positive HCC patients in general had a better prognosis than the DLC2-negative HCC patients. On the whole, our results strongly suggest that decreased DLC2 expression in HCC correlates with a poor prognosis for HCC patients.

\section{Conclusion}

Our results strongly suggest that decreased DLC2 expression in HCC correlates with cell differentiation of HCC and overexpression of RhoA, underexpression of DLC2 in HCC indicates a poor prognosis for HCC patients.

\section{Competing interests}

The authors declare that they have no competing interests.

\section{Authors' contributions}

LXR conceived of the study, performed the statistical analysis and drafted the manuscript. WW carried out the immunohistochemical staining. QLY carried out the western blotting assay. YKY participated in its design and helped to draft the manuscript. All authors read and approved the final manuscript. 

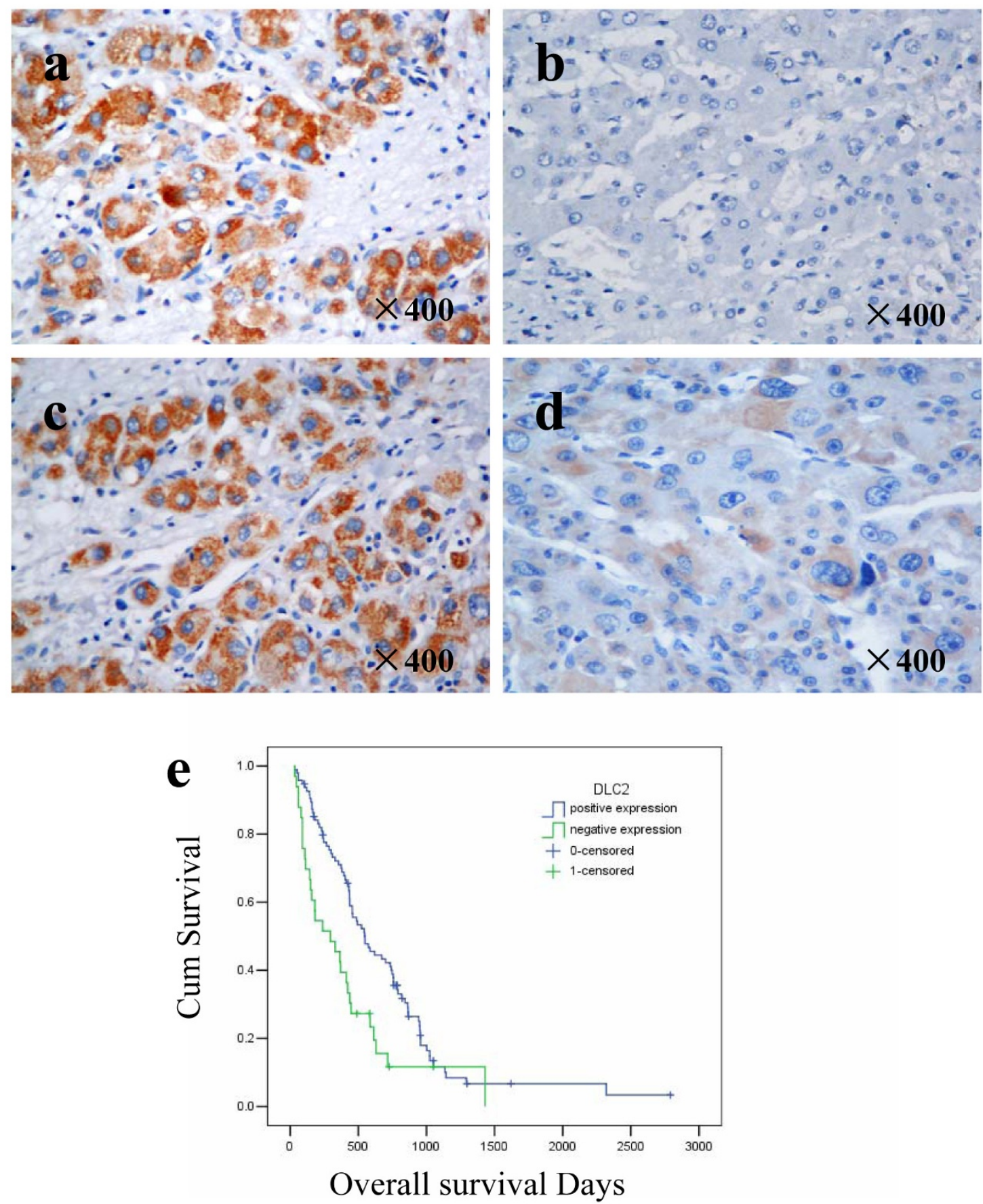

Figure 3

Correlation between DLC2 expression and prognosis of HCC. Expression of DLC2 protein was detected in 128 cases of HCC deparaffinized specimens by immunohistochemistry method. HCC specimen of DLC2 high expression confirmed by Western blotting was used as positive controls $(a)$, whereas negative controls were done by omitting the primary antibody (b). The representative positive expression of DLC2 (c) and negative expression of DLC2 (d) in HCC specimens were presented. Kaplan-Meier survival curves for DLC2-positive expression group $(n=33)$ and DLC2-negative expression group $(n=95)$ based on results of immunohistochemistry (e). HCC patients with DLC2-negative expression revealed significant poor prognosis than those with DLC2-positive expression, Log-rank test, $P=0.003$. 


\section{Acknowledgements}

We thank Wang Wei (Department of general surgery, xiangya hospital, CSU, Changsha, Hunan, P.R.China) for his critical and useful comments on manuscript.

\section{References}

I. Akriviadis EA, Llovet JM, Efremidis SC, Shouval D, Canelo R, Ringe B, Meyers WC: Hepatocellular carcinoma. $\mathrm{Br} J$ Surg 1998, 85:|3|9-|33|.

2. Murray CJ, Lopez AD: Mortality by cause for eight regions of the world: global burden of disease study. Lancet 1997, 349: 1269-1276.

3. Schafer DF, Sorrell MF: Hepatocellular carcinoma. Lancet 1999, 353: $1253-1256$.

4. Makuuchi M, Takayama T, Kubota K, Kimura W, Midorikawa Y, Miyagawa S, Kawasaki S: Hepatic resection for hepatocellular carcinoma - Japanese experience. Hepatogastroenterology 1998, 45: I267-I 274

5. Fan ST, Lo CM, Liu CL, Lam CM, Yuen WK, Yeung C, Wong J: Hepatectomy for hepatocellular carcinoma: toward zero hospital deaths. Ann Surg 1999, 229:322-330.

6. Bishop AL, Hall A: Rho GTPases and their effector proteins. Biochem J 2000, 348:24I-255.

7. Van Aelst L, D'Souza-Schorey C: Rho GTPases and signaling networks. Genes Dev 1997, I I:2295-2322.

8. Jaffe $A B$, Hall $A$ : Rho GTPases in transformation and metastasis. Adv Cancer Res 2002, 84:57-80.

9. Kamai T, Arai K, Tsujii T, Honda M, Yoshida K: Overexpression of RhoA mRNA is associated with advanced stage in testicular germ cell tumour. BJU Int 200I, 87:227-23I.

10. Fritz G, Just I, Kaina B: Rho GTPases are over-expressed in human tumors. Int J Cancer 1999, 8 I:682-687.

II. Kamai T, Tsujii T, Arai K, Takagi K, Asami H, Ito Y, Oshima H: Significant association of Rho/ROCK pathway with invasion and metastasis of bladder cancer. Clin Cancer Res 2003, 9:2632-264I.

12. Li XR, Ji F, Ouyang J, Wu W, Qian LY, Yang KY: Overexpression of RhoA is associated with poor prognosis in hepatocellular carcinoma. Eur J Surg Oncol 2006, 32: I 130-1 I34.

13. Ching YP, Wong CM, Chan SF, Leung TH, Ng DC, lin DY, Ng IO: Deleted in liver cancer (DLC) 2 encodes a RhoGAP protein with growth suppressor function and is underexpressed in hepatocellular carcinoma. J Biol Chem 2003, 278: 10824-10830.

14. Leung TH, Ching YP, Yam JW, Wong CM, Yau TO, Jin DY, Ng IO: Deleted in liver cancer 2 (DLC2) suppresses cell transformation by means of inhibition of RhoA activity. Proc Natl Acad Sci USA 2005, 102:15207-152/2.

15. Ng DC, Chan SF, Kok KH, Yam JW, Ching YP, Ng IO, Jin DY: Mitochondrial targeting of growth suppressor protein DLC2 through the START domain. FEBS Lett 2006, 580:191-198.

16. Wang W, Yang LY, Huang GW, Lu WQ, Yang ZL, Yang JQ, Liu HL: Genomic analysis reveals RhoC as a potential marker in hepatocellular carcinoma with poor prognosis. $\mathrm{Br} J$ Cancer 2004, 90:2349-2355.

17. Ullmannova V, Popescu NC: Expression profile of the tumor suppressor genes DLC-I and DLC-2 in solid tumors. Int J Oncol 2006, 29: I I27-I I32.

\section{Pre-publication history}

The pre-publication history for this paper can be accessed here:

http://www.biomedcentral.com/1471-2407/8/205/pre pub
Publish with Bio Med Central and every scientist can read your work free of charge

"BioMed Central will be the most significant development for disseminating the results of biomedical research in our lifetime. "

Sir Paul Nurse, Cancer Research UK

Your research papers will be:

- available free of charge to the entire biomedical community

- peer reviewed and published immediately upon acceptance

- cited in PubMed and archived on PubMed Central

- yours - you keep the copyright

Submit your manuscript here:

http://www.biomedcentral.com/info/publishing_adv.asp
BioMedcentral 